\title{
THE MORTGAGEES EQUITABLE INTEREST: BLOWER $v$. HEPBURN
}

PAMELA HALLETT*

In 1980, Mr. Justice Stevenson of the Court of Queen's Bench of Alberta, in the case of Blower v. Hepburm, ${ }^{1}$ held that goods which formed the subject-matter of a conditional sale contract, when subsequently mortgaged by the conditional purchaser, create in the chattel mortgagee an equitable charge on the mortgagor's interest and an agreement by the mortgagor to convey the legal title when acquired. This holding has significant implications for the financing of personal property transactions, having regard to the purposes and goals thereof. Its implications largely result from the pragmatic consequences of the labels "Legal" and "Equitable".

The problems resulting from judicial interpretation of the interests acquired under a chattel mortgage in the "true after acquired property" situation are thoroughly documented, with numerous articles written thereon. ${ }^{2}$ Generally speaking, judicial interpretation has been that a chattel mortgage on after-acquired property creates an equitable floating charge. The result of this has been to make secured financing in this kind of situation of limited usefulness, as an equitable interest creates a very unreliable security device.

Equally, the decision in Blower v. Hepburn creates the same type of problem but with respect to, it is submitted, a distinguishable situation. The consequence of the decision may be to defeat the purpose for which a security device is generally given, that being to secure the payment of a debt. The interpretation that an equitable interest only is created in situations like that in Blower v. Hepburn is not based on sound commercial policy: such interpretation effectively hinders the development of flexible forms of financing in the instance where a person holds property already subject to some type of security device.

That such results are undesirable, in both the "true after acquired property" cases and the Blower v. Hepburn type situation, is more evident by specific changes that have occurred in recent legislation dealing with secured transactions. For example, the new personal property security legislation presently in force in Manitoba and Ontario rids itself of the previously discussed anomalous interpretation. More specifically, the legislation extinguishes equitable interests and creates in the security holder a legal interest ${ }^{3}$ in "after acquired property".

* B.A., LL.B. (Alta.). Articling with Witten, Vogel, Binder and Lyons in Edmonton.

1. (1980) 13 Alta. L.R. (2d) 100.

2. Numerous articles have been written in the United States and Canada. For some discussion of this area, see D. Lee, "Secured Financing in Canada" (1980) 8 Alta L. Rev. 389; D. Cohen and A. Gerber, "The After-Acquired Property Clause" (1939) 87 U. Pa L. Rev. 635.

3. That the security holder has a "legal interest" is not, strictly speaking, correct. The use of the term is in essence a utilization of the pre-Act terminology. The Legal vs. Equitable distinction has in fact been abolished under the new legislation. However, in terms of the consequences flowing from the security holder's interest, it is "legal". 
The decision in Blower v. Hepburn on the point under discussion is not without authority. Mr. Justice Stevenson relied very heavily upon the Manitoba case of Reporter Publishing Co. v. Manton Bros. Ltd., ${ }^{4}$ a case seemingly on all fours with the facts in Blower v. Hepburn. In the Reporter Publishing case, a chattel was sold to the plaintiff under a conditional sales contract (as well as various other chattels) to $\mathrm{C}$, who executed in favor of the plaintiff a chattel mortgage. The plaintiff had the concurrence of the defendant for the sale of this chattel to $\mathrm{C}$ and obviously the plaintiff knew who had the legal title. $C$ subsequently traded in, to the defendant, the chattel subject to the conditional sales contract, taking another chattel in exchange. After default on the chattel mortgage, the plaintiff brought suit against the defendant to recover the chattel in question, offering to pay the unpaid balance at the time of the trade-in.

As Mr. Justice Stevenson noted, "The case was decided on the basis that $R$ [the plaintiff] relied on its chattel mortgage and $M$ [the defendant] on his position as legal owner accepting a surrender from $C$ without notice of the chattel mortgage to $\mathrm{R}$ [the plaintiff]."5 The court in Reporter held for the defendant, stating that although $\mathrm{C}$ had the right to grant a chattel mortgage on his interest in the property, ${ }^{6}$

any instrument purporting to assign chattels to be afterwards acquired can only take effect in law as a contract to transfer the legal ownership in such goods when they shall have been acquired ... and a mortgage of an interest in goods to be after-acquired confers an equitable interest only.

As the defendant was at all times the legal owner of the subject-matter and accepted a return of it from C, the defendant's legal title comes into conflict with the plaintiff's equitable title and the former must prevail. In reaching these conclusions, the court relied very heavily on the cases of Joseph v. Lyons ${ }^{7}$ and Gault Bros. Ltd. v. Winter. ${ }^{8}$

According to the judgment in Blower v. Hepburm, the facts thereof created "the same situation, Avco [the plaintiff] relying on its chattel mortgage and Derrick [the defendant] on its position as legal owner accepting a surrender from $W$ [the conditional purchaser]." 9 The facts were remarkably similar to those in the Reporter Publishing case although there were some significant differences. $C$ purchased a motor vehicle from the defendant under a conditional sales contract which was duly registered. Without the conditional seller's knowledge and representing to the plaintiff that legal title was vested in him, $\mathrm{C}$ placed a chattel mortgage also duly registered on the vehicle in favor of the plaintiff, purporting to "transfer, bargain, sell and assign" the full legal title. Subsequent to the execution of this mortgage, $C$ returned the vehicle to the conditional vendor seeking to trade it in on another vehicle and in fact did so, receiving credit for the amount already paid. The conditional vendor resold the original vehicle, $\mathrm{C}$ defaulted on his chattel mortgage and the plaintiff brought an action to determine what rights, if any, he had to the vehicle which was at this time under seizure.

4. Reporter Publishing Co. v. Manton Bros. Ltd. (1961) 35 W.W.R. 498, 29 D.L.R. (2d) 54 (Man. C.A.).

5. Blower v. Hepburn supra n. 1 at 101.

6. Supra n. 4 at 59.

7. Joseph v. Lyons (1884) 15 Q.B.D. 280, 54 L.J. Q.B. 1.

8. Gault Bros. Ltd. v. Winter (1914) 6 W.W.R. 608 (S.C.C.).

9. Supra n. 1 at 101 . 
Based on the assumption that we have here "the same situation" as in the Reporter Publishing case, a fortior i the same law applied. First, it was held that the mortgage of a chattel not owned by $\mathrm{C}$ created in the mortgagee an equitable interest, not a legal one. The legal title was vested in the defendant at all times. Consequently, the defendant's legal title would take priority over the plaintiff's equitable interest, in the absence of notice, as would the persons who purchased from the defendant. Because the conditional vendor did not have actual notice, and registration of the chattel mortgage under the Bill of Sales Act did not constitute notice (according to Mr. Justice Stevenson), judgment was given in favor of the defendant.

It is respectfully submitted that the aspect of the Blower v. Hepburn judgment concerning the interest acquired under a chattel mortgage on property subject to a conditional sales contract was wrongly decided. To the extent that the Reporter Publishing case is indistinguishable and inasmuch as the following discussion relates thereto, similarly it too is submitted to have been wrongly decided. The basis of these submissions rests primarily on the analogies relied on by the court with the "true" after acquired property cases.

It may be argued that the court in Blower v. Hepburn equated legal interest with legal title and it was on this basis that the analogy was drawn with cases like Joseph v. Lyons and Gault Bros. Ltd. v. Winter. In both the conditional sales situation and the situation where a person purports to mortgage property which he has not yet acquired (in any sense of the term), the party purporting to mortgage the goods does not have the legal title to those goods. Because of this similarity, in each kind of situation the party was, in the court's view, attempting to mortgage "property to be acquired in the future" and thus the analogy was drawn. However, the similarities end there; the positions and interests of all the parties in a conditional sale are distinctively different, more complex, and worthy of more scrutiny.

Assuming that the proposition "a mortgage on "after acquired property' creates an equitable charge only" is an acceptable one, some of the authorities relied on in the cases of Blower v. Hepburn and Reporter Publishing dealing with this issue should be examined in detail. The purpose of this examination will be to demonstrate that the two types of cases are in fact distinguishable and an analogy therewith, it is respectfully submitted, inappropriate.

Authorities abound dealing with property to be acquired by the mortgagor in the future. Those cases almost unanimously put forward the proposition that a purported mortgage on property to be acquired in the future gives the chattel mortgagee an equitable title or lien only. Two specific cases were cited and followed in the Reporter Publishing case, those being Joseph v. Lyons and Gault Bros. Ltd. v. Winter. In Joseph v. Lyons, the mortgagor purported to place a mortgage on stock in trade to be after-acquired. Before the mortgagee took possession, the mortgagor pledged some of the goods with the defendant who had no notice of the prior mortgage. The court held that the legal interest had remained in the mortgagor who transferred a legal interest to the defendant. As the mortgagee had only an equitable right, the defendant prevailed.

In Gault Bros. Ltd. v. Winter, a chattel mortgage purported to cover stock in trade and goods acquired by the mortgagor during "the conti- 
nuance of the security". In other words, at the time the mortgage was executed, the mortgagor purported to mortgage goods that had not even come into his possession yet, it being only a possibility whether he would ever acquire any interest in such goods. As would be expected, on the basis of Joseph v. Lyons, the court held that "the interest in after acquired goods under a mortgage of them when they come under the operation of the mortgage is an equitable interest only"..$^{10}$

Clearly in both of the above cases, the property which the mortgagor attempted to mortgage had been neither ascertained nor identified at the time the instrument was executed. The property was not in the possession of the purported mortgagor and in these cases, he had no rights with respect to it. In fact, whether or not he would ever receive such property in the future and in what quantity would be purely a matter of speculation. Considering the social implications of allowing a mortgagor to so bind himself by enabling him to create a legal interest in favor of others in property yet to be acquired by him, and the various other circumstances alluded to, it is little wonder the courts held that the mortgagor could only create an imperfect interest. Indeed, it is somewhat surprising that, at that period of time, the courts found that the instrument would be effective to create any interest, legal or equitable.

It is generally accepted under common law principles, that ${ }^{11}$

to make a valid legal mortgage, the thing which is the subject matter theréof must be ascertained or identified at the time of such grant or assignment and must actually belong to the mortgagor, or potentially belong to him as an incident of other property then in existence and belonging to him.

In short, at common law the rule was that 'a man cannot grant what he does not have.' This doctrine was reaffirmed in the case of Holroyd v.Marshall $^{12}$ which also sanctioned a security interest in after acquired goods, albeit only equitable. In the typical case dealing with the purported mortgage on after-acquired goods, the property is clearly not yet ascertained at the time the mortgage is executed, nor will the purported mortgagor have an interest therein. However, the same cannot be said with respect to the conditional sale situation.

In the typical conditional sale situation, the goods which form the subject matter of the contract have been identified and generally are in the possession of.the conditional purchaser at the time the chattel mortgage is executed. Moreover the purported mortgagor (the conditional purchaser) has an "interest" in the goods which is arguably legal but certainly more than "merely equitable" in the traditional sense of the term. Thus there can be no argument based on the proposition that even if the two types of cases are distinguishable, the mortgagee must still get only an equitable interest as the mortgage of an equitable interest can only create an equitable interest.

The argument that a conditional purchaser has nothing more than an equitable interest in the goods which form the subject matter of the conditional sale is not without its proponents. This question is crucial in this context as clearly, if the conditional purchaser in Blower v. Hepburn had no legal interest, on general common law principles he could not have granted to the chattel mortgagee a legal interest. Likewise, even if he had

10. Gault Bros. Ltd. v. Winter supra n. 8 at 622.

11. Jones, Mortgages on Personal Property (4th ed. 1894) 138.

12. Holroyd v. Marshall (1862) 10 H.L. Cas. 191, 11 E.R. 999. 
a legal interest, the mortgage document may not have been effective to transfer it, thereby giving the chattel mortgagee an equitable interest only. However, this latter possibility can be dismissed for, in Blower v. Hepburn (as might be contrasted with the Reporter Publishing case) had the conditional purchaser had any legal interest at all, the instrument used would have been effective to transfer it. Therefore, the question arises as to whether the statement, that a conditional purchaser has a legal interest, can be supported.

In examining various authorities dealing with the purchaser's interest under the conditional sales contract, the law is frequently trotted out as being that the purchaser gets neither title nor ownership to the goods in question, but only an equitable interest with a right to title by paying the full purchase price. ${ }^{13}$ Should this be taken to mean that a conditional purchaser has no legal interest whatsoever in the goods? It is suggested that the purchaser under a conditional sales contract has both an equitable and a legal interest in the goods. Likewise, an absolute legal title is not vested in the conditional vendor, but instead he retains only a qualified legal interest.

Typically, the cases dealing with the vendor's or purchaser's respective interests do not analyze these interests in an in-depth manner. However, the conclusions which can be drawn from the decisions illustrate that the interests of each are slightly nore complex than discussed, with the court finding a legal interest where the dicta would suggest there was none. Many cases support the proposition that the conditional vendor has something less than absolute title to the goods; that he has an interest in the nature of a qualified title. ${ }^{14}$ The qualification on the vendor's absolute title appears to be the purchaser's "right to redeem". Moreover, in analyzing the holdings in various cases, this "right to redeem" appears to be characterized by the courts as a "legal interest" or "legal right of redemption".

In Huether v. Waldsmidt, ${ }^{15}$ the conditional vendor seized goods originally sold under a conditional sales contract. He then purported to sell to a third party his "absolute title" in the goods prior to the expiry of the statutory period provided for redemption. The court held that the third party did not acquire an absolute title to the property free of the conditional purchaser's interest. Instead, the third party acquired the conditional seller's interest in the goods, that interest being one subject to the conditional purchaser's right of redemption. In accordance with generally accepted principles, the court noted that the Conditional Sales Act did not create but merely preserved rights and interests which had existed prior to the statute's enactment.

The significance of the decision in Huether $\mathrm{v}$. Waldsmidt lies in the method of analysis that must have been used by the court to reach the conclusion it did. That is, given due registration of the conditional sales contract to preserve the vendor's bona fide interests and assuming the third party acted without "actual" notice that the goods were originally subject

13. Workmen's Compensation Board v. U.S. Steel (1956) 18 W.W.R. (N.S.) 403 (Alta. S.C.T.D.).

14. See Re Mustard (1923) 54 O.R. 395 (S.C.A.D.); Toth v. Hilkeviks (1918) 1 W.W.R. 905 (Sask. C.A.); Sawyer v. Pringle (1891) 18 O.A.R. 218; Huether v. Waldsmidt (1923) 23 O.W.N.76.

15. Huether v. Waldsmidt (1923) 23 O.W.N. 76. 
to a conditional sales contract, the interest of the conditional purchaser must have been legal to prevail against the third party purchaser. Had the right of redemption been equitable, basic principles of equity would suggest that the third party would take free and clear of the conditional purchaser's interest, given that a purchaser of a legal interest without notice of a prior equitable interest takes free and clear of that equitable interest. It should be noted that the court did not deal specifically with the question of notice, a factor which might also lead to the conclusion that the right of redemption constitutes a legal interest.

At this point it may be contended that the court in the Huether case not so much regarded the right of redemption as legal but based its decision on the fact that to decide otherwise would render the provisions dealing with the statutory time period for redemption virtually of no effect. While such an argument may well be valid, it should be remembered that the same argument may be advanced in the Blower v. Hepburn situation. A conditional purchaser is given a specific right to mortgage his interst in goods bought under a conditional sales contract. Yet, to hold that this mortgage creates an equitable interest only is analogous to conferring no right to mortgage in certain situations. Thus, to give effect to the right conferred, as in Huether v. Waldsmidt, the conditional purchaser must be taken to have a legal interest.

The case of Pease v. Johnston ${ }^{16}$ also lends some support to the proposition that a conditional purchaser has a legal interest in goods which form the subject matter of a conditional sales contract. The case is also authority for the proposition that that legal interest can be transferred, by way of mortgage, to a mortgagee. In the Pease case, the defendant sold to one $J$ a pair of horses under a conditional sales contract. $J$ subsequently placed a chattel mortgage on those horses. J defaulted on the conditional sale contract and the horses were seized by the defendant. The question for the court was as to the plaintiff's rights with respect to the subject matter of the conditional sale contract. The court, noting that the defendant's right to seize was not disputed, held that the plaintiffs "were entitled to redeem the property and have it delivered to them on payment of that amount. ...

As is typical of most of the cases of this nature, the court did not deal with whether this "right to redeem" was a legal or equitable interest. Thus, given the circumstances of the case, it is of questionable value to suggest one way or the other. However, two particular circumstances do point to the conclusion that the interest was regarded as legal. First, the court mentioned that it was assumed for purposes of judgment that the conditional sale contract was duly registered. Therefore, the interest of the conditional purchase was effectively preserved and had he been the only person with a legal interest, he would take free and clear of any equitable interests of which he had no notice. Second, the court did not question whether the conditional vendor had notice of the plaintiff's chattel mortgage, suggesting that the chattel mortgagee had the right to redeem regardless. One way to justify this conclusion would be to suggest that the court regarded the right to redeem as a legal interest, transferred to the plaintiff by way of a chattel mortgage.

16. Pease v. Johnston (1905) 1 W.L.R. 208.

17. Id. at 213 . 
In the case of Re Mustard, ${ }^{18}$ the court considered the conditional vendor's "qualified title" and the purchaser's "right to redeem". In this case, the debtor bought goods under a conditional sale contract and subsequently made an assignment in bankruptcy. The claimants in the case had purchased from the conditional vendor the conditional sale contract. The court held that "when they [the claimants] purchased the lien notes, [they] purchased a redeemable interest only. If the debtor had not assigned, he could have redeemed by paying the amount due on the lien notes. The debtor having assigned, the right of redemption became vested in his trustee." ${ }^{19}$ In dealing specifically with the buyer's position under a conditional sales contract, the court noted that the buyer has a "right to pay and have the goods ... The buyer is always liable to pay the full price of the purchase and a right to redeem goes with such liability."20 Although the facts of the situation make any discussion of whether a right of redemption is a legal or equitable interest a matter of speculation, based on the tone of the decision one could argue that the right of redemption is a legal interest.

Sharp v. Inglis ${ }^{21}$ is typically cited as authority for the proposition that "both the buyer and seller under a conditional sales contract have such an interest therein as may be mortgaged". However on a closer examination, the case seems to lend support to a more extended proposition. It is submitted that this case would support the proposition that not only do a buyer and seller under a conditional sale contract have such an interest therein as may be mortgaged, but also that the mortgage of either interest, both being legal in nature, creates in the chattel mortgagee a legal interest.

In the Sharp case, a motor vehicle was sold to $F$ under a conditional sale agreement, duly registered. $F$ forthwith placed a mortgage on the vehicle, which again was duly registered. At the instance of creditors of the chattel mortgagor, the car was seized by the Sheriff and, having obtained the express consent of the conditional vendor, sold. The Sheriff gave a covenant of good title to the purchaser. The sum realized from the sale was paid out to the conditional vendor first and the balance to the creditors of $\mathrm{F}$ pro rata. The buyer at the Sheriff's sale transferred the vehicle to the defendant who in turn transferred it to the plaintiff. The vehicle was then seized by the mortgagee. The plaintiff sued for breach of the covenant of good title.

In holding for the plaintiff, the court said "the Sheriff was entitled therefore to sell only the interest of Firth [the conditional vendor] in the car". ${ }^{22}$ The court noted that the chattel mortgagee took subject to the conditional vendor's interest and then continued on, saying, "He had nothing to fear from a sale under a judgment subsequent in date to his mortgage". ${ }^{23}$ It was clear from the judgment that neither the Sheriff nor the purchaser from him had actual notice of the chattel mortgage. Nonetheless, the plaintiff's interest in the car was found to be subject to the interest of the mortgagee.

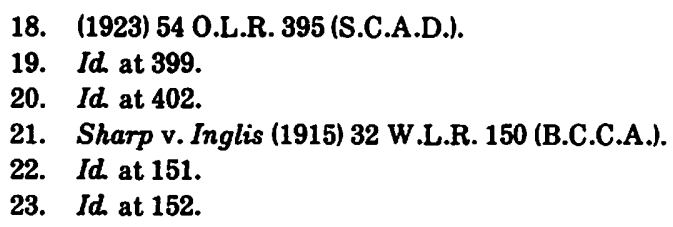


Undoubtedly the case of Sharp v. Inglis can be rationalized in a number of different ways, only one of which would suggest the proposition above submitted. It is arguable, however, that the case should be considered as follows. The position of the Sheriff in the Sharp case should be regarded as analagous to that of 'a trader selling in the ordinary course of business', the similarity between the two classes of cases being that both have the consent of the conditional vendor, be it express or implied, to pass his legal interest. ${ }^{24}$ Thus, once the goods were sold by the Sheriff in Sharp v. Inglis to a bona fide purchaser, that purchaser should get a good legal title to the goods assuming no other legal interest in addition to the conditional vendor's existed. Had the chattel mortgagee's interest been simply equitable, this "other interest" should have had no effect on the legal title of the purchaser from the Sheriff. However, indicating that the chattel mortgagee's interest was more than equitable, but in fact legal, the purchaser from the Sheriff and those subsequent to him took subject to the mortgagee's interest. That is, it was because of the mortgagee's interest that the covenant of good title was breached, which event would not have occurred had his interest been merely equitable.

Many cases discuss the numerous similarities between the respective interests acquired by a chattel mortgagee and mortgagor on the one hand and a conditional vendor and purchaser on the other. In Re Simpson ${ }^{25}$ the court held that the relationship between the buyer and seller under a conditional sale contract did not differ essentially from that of a mortgagor and mortgagee respectively. That being so, it is appropriate to examine a few of the cases dealing with the interest retained by a chattel mortgagor after granting a chattel mortgage.

In the case of Thomas $v$. Searles, ${ }^{28}$ the court was dealing with a situation where the owner of goods granted two bills of sale on the same goods. The statute in force at the time had a provision for avoiding a bill of sale except as against the grantor "in respect of any personal chattels ... of which the grantor was not the true owner at the time of execution of the bill of sale." ${ }^{27}$ It was argued that the second bill of sale was avoided as a bill of sale passes the entire property to the grantee, being different from a lien.

While the court did not discuss legal and equitable interests, the tenor of the Bill of Sales Act when combined with this judgment and others, seems to suggest that only a person with some form of "legal interest" in goods could, under this provision, grant a valid bill of sale' with respect to those goods. In the Thomas case, the court held that there was nothing in the statute to prevent a person from giving a second bill of sale on the same goods. In reaching this conclusion, the mortgagor's "equity of redemption" was referred to, the court holding that the mortgagor is the "true owner to the extent of that interest for the purpose of giving a fresh bill of sale as security ..." ${ }^{28}$ The court also noted that if such contention

24. There are numerous authorities dealing with the consequence of a trader selling, in the ordinary course of business, goods purchased under a conditional sales contract. The cases almost unanimously hold that where a trader sells in the ordinary course of business under the implied authority of the conditional vendor to do so, he will pass to a bona fide purchaser the legal ownership of the vendor in the goods.

25. (1927) 60 O.L.R. 310 .

26. [1891] 2 Q.B. 409.

27. Id. at 412 .

28. Id. 
as the one advanced were accepted "the facilities for raising money by bills of sale would be enormously curtailed." 29

The case of Thomas v. Searles when considered alone, is of limited value in advancing the proposition that a mortgagor, like a conditional purchaser, has a legal interest which may be mortgaged. However, certain of the dicta do indirectly lend support to this proposition. For example, the court, in finding as it did, was persuaded by the consequences of holding otherwise. Considering the limited value of an equitable interest as a security device, the court must have considered the mortgagor's interest to be legal as was the grant to the second mortgagee, given that this would be a prerequisite for a fully effective security device. But more importantly, the above proposition is greatly strengthened by considering Thomas v. Searles in combination with another case which considered the same section of the Bills of Sale Act.

The case of Lewis v. Thomas ${ }^{30}$ interpreted the words "true owner" as used in s.5 of the Bills of Sale Act (1878) Amendment Act, 1882. ${ }^{31}$ In that case, the hirer under a hire-purchase contract executed a bill of sale on the subject matter of the hire-purchase contract. Under the terms of the contract, the hirer had no obligation to pay; a fortiori he had no right of redemption. The County Court Judge held that the hirer had an equitable interest and therefore, for the purposes of the Bills of Sale Act, was the "true owner". On appeal, the court held the bill of sale invalid except as against the grantor.

The position of the hirer under a hire-purchase agreement is distinguishable from the position of both a chattel mortgagor and conditional purchaser. Under a typical hire-purchase agreement, the hirer is not bound to purchase the subject matter of the agreement and similarly there is not vested in him a right of redemption. Nonetheless, the hirer is typically characterized as having an equitable interest in the goods. In Gordie \& $M c C$ Culloch Co. v. Harper the court said that the effect of a hirepurchase agreement, quite apart from statute is that "the vendee is not a mere hirer of the property, but is the equitable owner of it, subject to the payment of the purchase money...".32

How then can Lewis v. Thomas and Thomas v. Searle be reconciled? If the position is taken that the chattel mortgagor's right of redemption is equitable only, the difficulty of reconciliation becomes apparent. While not completely devoid of possibility, it is unlikely that the courts are differentiating "true owners" on the basis of variants of "equitable interests". On the contrary, it is much more likely that a true owner is one with some form of legal interest which both the chattel mortgagor and the conditional purchaser can be said to have.

Assuming the conditional buyer has a legal right of redempton, there is no question but that he can mortgage that interest. Sharp v. Inglis specifically holds that "both the buyer and seller on a conditional sale of goods have such an interest therein as may be mortgaged". ${ }^{33}$ Pease v. Johnston, in holding that "the buyer or anyone claiming through him is

29. Id.

30. Lewis v. Thomas [1919] 1 K.B. 319.

31. 45 and 46 Vict., c. 43.

32. Gordie \& McCulloch Co. v. Harper (1899) 31 O.R. 284.

33. Supra n. 21 at 152. 
entitled to redeem the property upon payment of the amount due thereon and the actual necessary expenses of taking possession", ${ }^{34}$ leads one to the conclusion that there is no issue as to whether a conditional purchaser can mortgage his legal interest in the goods. On this basis, assuming the instrument is effective to transfer a legal interest, as to which there is no question in Blower v. Hepburn, one may conclude that the mortgage of goods subject to a conditional sales contract creates in the chattel mortgagee a legal interest.

Therefore, despite the precedent which may exist as to the effect of mortgages granted on goods to be "afterwards acquired," there is no solid basis on which to hold that the same result flows from a mortgage of goods which form the subject matter of a conditional sales contract. The two types of cases are clearly distinguishable and the "stock in trade" cases may be removed as precedents. However, on still another ground it may be argued that the court should have found that the mortgage by the mortgagor in Blower v. Hepburn created in the mortgagee a "legal interest," albeit subject to the rights of the conditional vendor. Moreover, this should have been so found regardless of how the conditional buyer's interest be characterized.

As previously discussed, there exists at common law the principle that 'a man cannot grant or charge what he does not have.' If it were to be assumed that under a conditional sales contract, the conditional purchaser has only an equitable interest, it follows, based on this principle, that he can grant to the chattel mortgagee only that equitable interest. But, to every principle there seems to be at least one exception, and this principle is not different in that regard. Consequently, even assuming that the conditional purchaser had only an equitable interest, it need not necessarily follow that he could not have granted unto the mortgagee a legal interest.

As early as 1616 , in the case of Grantham v. Hawley, ${ }^{35}$ the court began to "chip away" at the strict common law principle, recognizing the need for and benefits of being able to utilize "future property" to secure present advances. The end result of the case was to allow a sale (in the sense of passing legal title) or a mortgage (of a legal interest) of chattels not yet in existence. However, this exception was limited in the sense that "the basic substance which yields the increment must be owned by the vendor or mortgagor. ... The doctrine rests ... upon the fiction that a man may own something that is not yet in existence but which in the normal course of events will come into being". ${ }^{36}$

It is submitted that owing to the peculiar nature of the conditional buyer's "equitable or other" interest, a case such as Blower v. Hepburn should be brought within the exception enunciated in Grantham v. Hawley. To lend support to this submission, it is necessary to examine the cases which have held, in essence, that 'a man can effectively grant what he does not have'. In Cameron v. Gibson, ${ }^{37}$ A.C., as owner of the equity of redemption in lands, sowed a quantity of wheat and granted a chattel mortgage thereon to the defendant, which chattel mortgage was duly

34. Supra n. 16 at 211.

35. Grantham v. Hawley (1616) Hobart 132, 80 E.R. 281.

36. Cohen and Gerber, supra n. 2 at 636.

37. (1889) 17 O.R. 233. 
registered. Prior to harvest, A.C. conveyed the lands to $H$, one of the mortgagees of the land. $H$ then leased the property to the plaintiff. Upon the wheat ripening, the plaintiff harvested it, whereupon the defendant seized it under his chattel mortgage. The plaintiff brought action to recover.

The court held in favor of the chattel mortgagee, finding that H's right to the crops as part of his security for the mortgage had merged by his taking a conveyance of the lands. Thus, the chattel mortgage to the defendant became prior in time to the title under which the plaintiff claimed. The court noted that the defendant had become ${ }^{38}$

the owner of them [the crops] by his chattel mortgage at the time it was executed, but subject always to the chance that Hay, the mortgagee of the land, might exercise his right to enter into possession and take them before they were reaped. The mortgages were paid off ... [Consequently] the conveyance from A.C. to $\mathrm{H}$ passed the land subject to the existing rights of the defendant under his chattel mortgage of the crops; and the lease passed ... no greater interest.

There are two points worthy of mention and which arise from this case. First, as is apparent from the language used by the court, the decision reached and the interpretation of this case in cases subsequent to it, ${ }^{39}$ the court held that the mortgage of chattels not yet in existence as "chattels" created in the chattel mortgagee a "legal" interest in those "chattels". Moreover, this legal interest was created at the time of the granting of the mortgage and not some point subsequent thereto. Second, A.C., who was both the chattel mortgagor and the mortgagor of the lands, under the law as it existed in 1881, had only an "equity of redemption" in the lands at the time he granted the chattel mortgage.

Another type of case where a chattel mortgagor has been held capable of granting or creating a legal interest on the chattel mortgagee at a point in time when he has no legal interest or title in the chattel himself is the 'natural increase cases'. In Roper v. Scott ${ }^{40}$ the owner of two mares granted a chattel mortgage on those mares in favor of the defendants. The mortgage purported to include the natural increase from the mares. During the continuance of the security, which had been duly registered and properly renewed, the mortgagor sold three colts to three separate plaintiffs, who were all bona fide purchasers without notice.

Counsel for the plaintiff contended that "the same rule of law should be applied in this case as in the case of a mortgage of goods to be acquired in the future". ${ }^{1}$ Consequently, the plaintiff's title to the colts would prevail against the defendant, the legal estate and interest having vested in them without notice of the defendant's equitable right, and prior to any taking of possession by the equitable mortgagee.

After due consideration of this argument, the court specifically rejected it, holding that the defendant had the legal estate in the offspring of the mares, subject to the mortgagor's equity of redemption. "If the mortgagor sold the foal to a third party for value [which he did], the latter would not acquire the legal title, he would only take an equitable

\footnotetext{
38. Id at 238.

39. See Unrau v. Barrowman (1967) 59 D.L.R. (2d) 168 at 182, which case cites Cameron v. Gibson as authority for the proposition that once grain had been sown, that grain becomes a chattel asset with title and right of ownership exclusively in that person who has sown the grain, even though that person may be a trespasser on the land.

40. Roper v. Scott (1907) 5 W.L.R. 341 (Man. C.A.).

41. Id. at 343 .
} 
interest". ${ }^{42}$ Consequently, the defendant's "claim should prevail as against the mere equitable right of a purchaser for value without notice". ${ }^{43}$ In justifying this conclusion, the court cited the "common law rule that the progeny belongs to the owner of the dam, then the ownership of the foal would, at common law, be in him who at common law was the owner of the mare". ${ }^{44}$ As the chattel mortgagee was the owner of the mares in law, likewise he was the owner of their progeny.

With all due respect, it may have been more appropriate in Blower $\mathrm{v}$. Hepburn, and indeed in the Reporter Publishing case, to have drawn the analogy with these two cases rather than Joseph v. Lyons and the Gault $B r o s$. case. This, however, is not to suggest that there is no argument that cases such as Joseph v. Lyons and the other "after acquired property cases" should not as well be brought within this exception. It could, on the basis of sound principle, be contended that this exception should be extended to the after-acquired property cases. For example, just as a person may have a crop or progeny from his stock in the future, in the normal course of events, so might he also acquire certain chattels in the ordinary course of his business.

The above position seems to have been adopted in certain of the earlier after acquired property cases. For example, looking a the language used in Reeves v. Barlow ${ }^{45}$ this case might well be cited in support of the proposition that a mortgage of after-acquired property creates a legal interest in the mortgagee. However, it is clear that the authority is overwhelming that such an argument would be difficult to make and far beyond the scope of this paper. Nonetheless, if it can be suggested that the Grantham v. Hawley principle ought to have been extended to the after-acquired property cases, certainly the position is much stronger in favor of extension to the Blower v. Hepburn situation.

On what basis should the analogy be drawn? In all three cases, Blower v. Hepburm, Cameron v. Gibson and Roper v. Scott, the mortgagor "potentially" had title to the property in question. Moreover, the likelihood of not obtaining title to the "potential" property could not be said to be any greater or less in one case than in another. Assuming the normal course of events, an assumption implicit in the Cameron and Roper cases, title to the vehicle in Blower v. Hepburn would have vested in the mortgagor. Thus, he should have been able to create a legal interest in the mortgagee on the basis of Cameron and Roper.

It has previously been stated that the excepton in Grantham v. Hawley was limited in the sense that 'the basic substance which yields the increment must be owned by the vendor or mortgagor'. Clearly, on the basis of Cameron v. Gibson, this limiting factor seems to be no longer required, as the mortgagor only had an "equity of redemption" in the land, which could be considered the "basic substance". Thus, this poses no problem in the drawing of an analogy. Moreover, even if this is a requirement, an argument could be made that the mortgagee in Blower v. Hepburn owned the conditional sales contract which constituted 'the basic substance which would yield the increment'.

42. Id. at 345 .

43. Id.

44. Id.

45. Reeves v. Barlow 12 Q.B.D. 
There are many levels on which an analogy can be made. Equally, some of the reasons that can be put forth to strengthen this argument also provide a basis on which to distinguish the "after acquired property" cases. For example, in all three cases referred to, the "process" leading to legal ownership had been commenced, whereas in the after acquired property cases no such argument can be made. As well, there are reasons that can be put forth suggesting that the Blower v. Hepburn type situation is a better candidate for an exception than either the Cameron or Roper case. In this regard, it could be mentioned that the "property" in Blower v. Hepburn was more "identifiable than that in Roper v. Scott at the time of granting the mortgage. This is an important consideration of the court in considering whether a legal interest has been granted.

Thus, in conclusion and with reference to Blower v. Hepburn, it is submitted that the conditional buyer had a legal interest in the goods subject to the conditional sales contract. That interest could be mortgaged and in fact was, given the terms of the chattel mortgage in the Blower case. Consequently, the vehicle in the hands of the conditional vendor and the third party purchaser was subject to the chattel mortgagee's legal interest.

Alternatively, it is respectfully submitted that even if the conditional buyer did not have a legal interest in the goods, an analogy between this case and cases like Cameron v. Gibson and Roper v. Scott can be drawn. As a result of drawing this analogy, it should have been found that the chattel mortgagor, whether his interest be legal or equitable, due to the peculiar circumstances, created in the mortgagee a legal interest subject to the rights of the conditional vendor. It is for these reasons that Blower v. Hepburn was wrongly decided.

Assuming either of these submissions is correct, the issue of notice does not arise. However, if this conclusion incorrect, the question of whether registration constitutes notice becomes a crucial issue. In the latter event, it would be difficult to maintain that this aspect of the case was wrongly decided. While the position of counsel for the mortgagee is not without merit, Mr. Justice Stevenson conducted a comprehensive review of the authorities and concluded registration was not notice. Considered in this light, the decision on the notice issue cannot be attacked. 